\title{
THE SEARCH FOR AN AUTHOR: SHAKESPEARE AND THE FRAMERS*
}

\author{
JAMES D.A. BOYLE**
}

How can one reduce the great peril, the great danger with which fiction threatens our world? The answer is: One can reduce it with the author. The author allows a limitation of the cancerous and dangerous proliferation of significations within a world where one is thrifty not only with one's resources and riches, but also with one's discourses and their significations. The author is the principle of thrift in the proliferation of meaning.

Michel Foucault, What Is An Author ${ }^{1}$

\section{INTRODUCTION}

For a brief period in the nineteen seventies it became fashionable to write thrillers in which there was no central narrator, merely a collection of official and unofficial documents out of which the story would appear, apparently rising to the surface of the text under its own power. The briefs and opinions which follow in this volume could be seen in the same light. Unfortunately, the narrative is a rather bare one. There is a controversy over the true identity of Shakespeare, a controversy notable for the intemperate statements to which it gives rise. Three Supreme Court Justices agree to hear a staged oral argument on the issue. Briefs are written, and replies.

* (C) 1988 James D.A. Boyle

* Professor of Law, Washington College of Law, The American University.

Thanks go to many people. To David Lloyd Kreeger and Fred Anderson for setting up the debate, to the Justices for being so gentle with the nervous lawyers, to Lauren Dame for all her help and support, to Mern Horan amd Phoebe Schlanger for helping so much with the research, to Jeanne Thomas for her suggestions, to Peter Jaszi who is everything a colleague should be, to Shailu Iyengar for 3 a.m. typing, and to the editors of the Law Review for their forebearance. My thanks go to all of these people but this article is dedicated to Samuel Schoenbaum. Professor Schoenbaum was kind enough to allow his works to be part of the record for the case and to recommend to me certain works on the subject. For this kindness he received only the most dubious of rewards. I commend Mr. Schoenbaum's beautifully written and charmingly humorous Shakespeare's Lives to the reader as an example of what Shakespearean scholarship should be like.

1. Foucault, What Is in Author?, in Textual Strategies; Perspectives In Post-Structuralist Criticism 146, 158-59 (J. Harari ed. 1979). 
(These you have.) There is a televised oral argument. (This you do not have.) The court decides in favor of the traditional claimant to Shakespeare's laurels, each Justice rendering a separate opinion. (The opinions, too, are provided.) The attorneys retire in some confusion, unaccustomed to the importance they are presumed by their audience to possess. The parties disperse, already arguing over the significance of the ruling.

Apart from the rather bizarre subject matter, the media attention and the eminence of the panel, it sounds like a typical piece of litigation. But behind this bare narrative lies another story, as full of strange personalities, unlikely arguments, and philosophical puzzles as Umberto Eco's, The Name of the Rose ${ }^{2}-\mathrm{a}$ book about semiology masquerading as a murder mystery.

Since the editors of the law review have unwisely given me carte blanche in writing this essay, I want to concentrate on this second narrative, the strange subtext that lies under the Shakespeare story, and to link it to current philosophical and literary concerns about the reading of texts. Seen this way, the Shakespeare debate is an example of something we also find in arguments over "the Original Intent of the Framers"-an attempt to give epistemological precedence to one particular reading of the historical and textual record. The interesting difference is that constitutional scholarship uses the intention of the authors to identify the meaning of the text, while much of the Shakespeare scholarship uses the meaning of the text to "identify" the author-and not just by name. In both cases, however, we find the phenomenon described by Foucault in the quotation which heads this essay-the use of the Author as the principle of thrift in the production of meaning, a device that limits and disciplines the range of meanings to be found in the text.

Just as the "Intent of the Framers" is used as an argumentative device to limit the range of interpretations of the Constitution, so the Shakespearean biographies seek to invent a richly detailed picture of the author, a picture which can then be used to constrain the interpretation of the very works from whence it was drawn. At the same time the biographer may even be able to use "Shakespeare" as a cheerleader for some particular opinion about politics, sexuality, you name it. (And they have.) For those who cannot believe the biographies thus constructed, why there is always the option of substituting for the mysterious William Shakespeare some other author about whom we do know a great deal, such as Edward de Vere, or Queen Elizabeth, or Bacon, or Marlowe, or. . Both sides, in other

2. U. Eco, The Name Of The Rose (1983). 
words, seem driven to construct or discover a definite author who will then give definite meaning to the work, in just the same way as the Framers are thought to give a definite meaning to the Constitution. In this essay, I will explore this beguiling similarity. My argument is that the Shakespeare debate has much to tell us about attitudes to textual indeterminacy and to the romantic picture of the author on which so much of our interpretive tradition-both constitutional and literary-depends.

When the Shakespeare debate was first proposed to me, I had only the haziest knowledge of the arcane world of Shakespeare "claimants." I knew a little more about Shakespearean scholarship generally, and had an interest in the world of Elizabethan professional playwrights. Being by disposition an aspiring iconoclast, I was sympathetic to the idea that the traditional learning might be wrong and receptive to the idea that a scholarly consensus can be repressive as well as enlightening. I am sorry to say that I found the various attempts to dethrone William Shakespeare as the true author and to crown any one of fifty-six claimants in his stead, to be almost entirely without merit as investigations into historical fact. But what they lacked as assertions of historical truth, they more than made up in the richness and depth of their rhetorical structure, their baroque assemblies of circular arguments, their obsessive and recurrent themes of conspiracy and foul-play, their superlative ability to explain away inconvenient evidence, their ahistorical and romantic conception of authorship, and finally their beneficial effect in getting the Shakespearean orthodoxy to reconsider its own fanciful historiography. What is more, some of the Stratfordian scholarship shared the same faults. In fact, it seemed to display an identical structure. It is on this structure that I wish to concentrate. Thus, I must advise those who wish to concentrate on the debate tout seul to turn directly to the briefs. In this introductory article I will be exploring not the debate over a fact, but the morphology of an obsession-the obsession with Shakespeare's author-ity.

As part of my preparation for the debate, I read a great deal written by "the heretics"- the revealing name given to those who do not think that the actor from Stratford wrote the plays. There are some fifty-six claimants to Shakespeare's throne ${ }^{3}$-some of whom are supposed to have worked alone, while others are supposed to

3. See H. Gibson, The Shakespeare Claimants (1962). 
have collaborated in the most unlikely assemblies. Each champion for a claimant generally begins with a short autobiographical description of how he or she came to doubt that Shakespeare was truly the author. Almost without exception, the reason cited is the lack of fit between William Shakespeare's life and "Shakespeare's" works. They express surprise that we know so little about Shakespeare's life. Surely a transcendental genius would have left us more records? They express surprise at the kinds of records that he did leave us. Surely a great artist would not have been as interested in the getting and making of money? After all, we all know that great art is inimical to commerce and worldly concerns. They express surprise over the fact that Shakespeare apparently committed the sin we call plagiarism. Surely a great artist would not have stooped to copy the works of his inferiors? They express surprise that Shakespeare did not seek greater control over his own works; some of them being published without his name and apparently without his consent. Surely, nothing is more important to a great artist than to control the rights to and the attribution of his own works? Finally, they express surprise that Shakespeare had a command over such a wide range of information. Where did he get the opportunity to load up with all of this (to our eyes, arcane) knowledge, before spilling out in the plays?

I think that it is in this part of the debate that we get the clearest view of the conception of the author that animates both the heretical and the more extreme Stratfordian works-the latter being traditionally and revealingly referred to as "bardolatrous," because they construct an idolatry around the bard. In fact, I would like to make the claim that most of the debate over who wrote "Shakespeare's" works really reduces itself to a debate over different conceptions of authorship. ${ }^{4}$ Both the heretical and the bardolatrous theories depend on a vision of authorship which I shall call the romantic vision. ${ }^{5}$ In the romantic vision art (and authorship in particular) is

4. Professor Marjorie Garber was, to my knowledge, the first person to raise this issue in connection with the debate over the identity of "William Shakespeare." I am enormously indebted to her essay, Shakespeare's Ghost U'riters, in Cannibals, Witches ANd Divorce: EsTRANGING THE RENAISSANCE (M. Garber ed. 1987). Apart from the Foucauldian perspective suggested here, Professor Garber also traces out a fascinating series of subplots within the debates-including the attempt by Americans to bring Shakespeare to the New World by discovering his "true" identity. I cannot recommend her work highly enough.

5. I pick this term because it has many of the connotations central to the popular conception of authorship. For background to the discussion see Foucault, supra note 1; Woodmansee, The Gemius and the Copyright: Economic and Legal Considerations of the Emergence of the "Author", 17 Eighteenth Century Studies 425 (1984); see also J. Ralph, The Case Of Authors By Profession Or Trade (1758); P. Sheavyn, The Literary Profession In The ElizAbethan Age (1909); Darnton, A Police Inspector Sorts His Files: The Anatomy of the Republic of Letters, in R. Darnton, The Great Cat Massacre And Other Episodes In French Culturat. 
inimical to commercial concerns. The writer does not write for money, nor is she interested in anything other than the perfection of her work. The author is presumed to have an almost transcendental insight-something which cuts beneath the mundane world of everyday appearance. This transcendental insight or genius plays a very important role in establishing the author as the ruler of the text. It "goes without saying" that the author's interpretation governs because it is the author's genius, the author's special knowledge, which created this piece of art ex nihilo. Similarly, the argument for original intent relies in part on the idea of the Founding Fathers as both literal and figurative "authors" of the Country. Thus, their understanding of the Constitution should govern us, not only because of their role as creative genii, but because-“by convention"- - an author's interpretation is the "governing" one.

The romantic conception of authorship gives the author more than mere interpretive control over the work. In many Western countries, (though not in most parts of the USA) copyright laws go so far as to recognize the author's "moral rights" to control a work. "Independently of the author's economic rights, and even after the transfer of the said rights, the author shall have the right to claim authorship of the work and to object to any distortion, mutilation or other modification of, or derogatory action in relation to, the said work, which would be prejudicial to his honor or reputation."'6 So deeply rooted is our sense that art and authorship are different than other kinds of market transactions, that it is difficult to realize how striking a provision this really is. Could we imagine giving a plumber a control over the pipes she installs even after the work is paid for, or a cabinet maker the right to veto the conversion of her writing desk into a television cabinet? ${ }^{7}$ The author is different than other workers, is outside the ordinary world of work and exchange, precisely because of her romantic status. In only one other area, the family, does our society have a similar romanticism, a similar anticommercialism, a similar commitment to non-instrumental relationships. And, like the family, the author's work provides us with a "haven in a heartless world." 8 How terrible it would be then, to find that the greatest author of all was a professional playwright who

History 145, 162-63 (1984); C. Davidson, Revolution And The Word: The Rise Of The NOVEL IN AMERICA (1986). $41(1978)$.

6. Article 6 bls, Berne Convention, W.I.P.O. GUIDE TO THE BERNE CONVENTION

7. Well, admittedly, some of us can imagine such a world. See Marx, Estranged Labour, in Tuf MarX-Engels ReAder 56 (R. Tucker ed. 1972).

8. Sie C. Lasch, Haven IN A Heaktless World (1977). For a fascinating account that arguably fuses the romantic conception of the author and the romantic conception'of the 
knocked out scripts for money, and made canny investments of the proceeds. How bizarre it would be if, while showing great concern over the management of his real estate, Shakespeare did not protest pirated, corrupt, or unauthorized versions of his work. ${ }^{9}$

Finally the author is indulgently expected to have a character, a temperament, and a genius that put her outside of society, just as the Founders are conceived as being outside of, being prior to politics, which is something that goes on inside the structure they have created. This peculiar outsider's status confers an unusual power upon the author's subjectivity. The author is seen as the individual par excellence. "The coming into being of the notion of 'author' constitutes the privileged moment of individualization in the history of ideas, knowledge, literature and the sciences."10 Society is supposed to allow the author more subjectivity than the average person. She may be eccentric or violate cultural norms. Her genius is seen as individual rather than being the product of a culture or a context. To understand the work we concentrate most of our attention on the author, rather than on the learning of the time, the gossip of the streets, the influences of the genre. The work comes from inside the author. At best, we may concede that this particular author is fitted by breeding and education to be its enunciator. And if we do not stress the importance of culture and context to the formation of the romantic author's work, still less do we even entertain the notion that she could possibly have taken any of her work from the work of others. The romantic author may violate the norms of sexuality, decorum, and social propriety, but never the norms of literary property. How horrific then, to think that the greatest author of them all would "borrow" freely from the works of his contemporaries. ${ }^{11}$

The romantic conception of authorship should seem familiar. Today it dominates popular conceptions of the "great writer." What is more, we project it back through history, we universalize it. Not only do we think this is the way that authors are now, we think it is

family see Darnton, Readers Respond to Rousseau; The Fabrication of Romantic Sensilivity, in R. DARNTON, supra note 5 , at 215.

9. For a discussion of these "anomalies" compare Appellant's Brief at pp. 680-81 with Appellee's Brief at 769-70.

10. Foucault, supra note 1 , at 141 .

11. "With Elizabethans, stories, ideas, even phrases, were regarded as common literary property which anyone could translate or adapt." K. HOLZNECHT, BACKGROUNDS OF SHAKESPEARE'S PLAYS (1950), quoted in Appellee's Brief at n.108. Compare this to a typical Oxfordian reaction. "I have rejected the contention of the Stratfordians, insulting to the peerless dramatist and unreasonable on its face, that Shakespeare stooped to cribbing the grosslv inferior work of others." C. Ogburn, The Mysterious William Shakespeare 449 (1984). If this isn't an ahistorical vision of authorship, it is hard to imagine what would count as one. 
the way they have always been. But this conception of the status of authorship, of the relationship of art to commerce, of literary property, of the illegitimacy of "borrowing" from other works-is actually a comparatively modern one. It would certainly have been alien to Shakespeare. It would be both presumptuous and ridiculous to attempt here a complete history of the concept of authorship, although one is definitely needed. Nevertheless, a series of historical snapshots may suffice to show the historical contingency of our present ideas about the relationship of authorship to genius, interpretation, control, and commerce.

In medieval Europe authorship did not have the preeminent importance or the significance we accord to it today. The early Church writers, who were also the guardians of literacy, saw literary and philosophical creation as a less important task than that of preserving the wisdom of the ancients.

They valued extant old books more highly than any recent elucubrations and they put the work of the scribe and the copyist above that of the authors. The real task of the scholars in their view was not the vain excogitation of novelties but a discovery of great old books, their multiplication and the placing of copies where they would be accessible to future generations of readers. ${ }^{12}$

To the extent that literature became a pastime of noble courtiers, the idea of a permanent "work of art" remained foreign to the genre. "Even the courtiers themselves seem dubious about these kinds of literature outside the limits of the intimate circles for which they were primarily intended: maybe the art is too frivolous to deserve the permanence of print." 13 At the same time the fact that the literature was aimed at a small circle of courtiers meant that it was seen as communal property, making the modern ideas of individual production, control, and ownership doubly inappropriate. ${ }^{14}$ Ironically, these are the best arguments Oxfordians have so far put forward to explain Edward de Vere's "failure" to acknowledge Shakespeare's works as his own, although they will need to jettison some of their beloved conspiracy theories to make these arguments credible. Yet once one accepts the fact that authorship was seen differently in Elizabethan times, one cannot excoriate poor Will for his failure to live up to another era's concept of literary creation. What one gains on the roundabout one loses on the swings.

12. E.P. Goldschmidt, Medieval Texts And Their First Appearance In Print 112 (1943), qualed in J. Saunders, The Profession Of English LetTers 20 (1964) (emphasis added).

13. J. SAUNDERs, supra note 12 , at 60.

14. Id. at 46 . 
How was the author-and in particular the playwright-seen during the period that Shakespeare was writing? The best evidence suggests that the closest contemporary parallel may be to the early history of the film industry. ${ }^{15}$ There one finds a group of working professionals who knocked out film after film, collaborating, "borrowing" from each other, viewing themselves as journeymen and women who were laboring together to develop a new (and profitable) craft. In retrospect their films have been granted the status of "works of art"- a concept with connotations which would probably have been alien to the understanding the people involved had of their own products, just as it would have been alien to Elizabethan playwrights. ${ }^{16}$ Admittedly, Elizabethan authors hoped for an improved social and intellectual status. ${ }^{17}$ So, I am sure, did filmmakers. But the wish is not the reality, and "an improved status" is not necessarily the particular status we now give to authors and works of art. Indeed, well after the Renaissance, there is evidence that the author was just seen as one of the many people who labored together to produce a book. Martha Woodmansee illustrates this point with the entry on "Books" from the Allgemeines Oeconomisches Lexicon, published in 1753.

Book, either numerous sheets of white paper that have been stitched together in such a way that they can be filled with writing; or, a highly useful and convenient instrument constructed of printed sheets variously bound in cardboard, paper, vellum, leather, etc. for presenting the truth to another in such a way that it can be conveniently read and recognized. Many people work on this ware before it is complete and becomes an actual book in this sense. The scholar and the writer, the papermaker, the type founder, the typesetter and the printer, the proofreader, the publisher, the book binder, sometimes even the gilder and the brassworker, etc. Thus many mouths are fed by this branch of manufacture. ${ }^{18}$

Professor Woodmansee points out that the Renaissance vision of authorship was a strange combination of the notion of "craft" and

15. This vision comes from lengthy talks with Peter Jaszi whose expertise in early American film is not easily cited. I suggest The Cinema Book 2-8, 114-206 (P. Cook ed. 1985): B. HaRPER-Fussell, Mabel 53 \& passim (1982).

16. I am not disputing the quality of Elizabethan theatre and early American film. merelv pointing out that if we cram them into the Procrustean bed of our romantic conception of art-the great work conceived by the great author-we lose any real understanding of how these cultural artifacts were actually produced.

17. J. SAUNDERS, supra note 12 , at 80 .

18. G. Zinck, Aligemeines Oeconomisches Lexicon col. 442 (1753), quoted $m$ woodmansee, supra note 5 , at 425 . I am grateful to my colleague Peter Jaszi for drawing my attention to this excellent essay. 
inspiration. Both craft and inspiration were external-the craft consisted of applying a body of received learning and the inspiration came from the deity or the muse. In this "compound model" the element of "individuation" of which Foucault speaks is absent; the work comes from outside of the author, from the culture or the Gods.

Eighteenth-century theorists departed from this compound model of writing in two significant ways. They minimized the element of craftsmanship (in some instances they simply discarded it) in favor of the element of inspiration, and they internalised the source of that inspiration. That is, inspiration came to be regarded as emanating not from outside or above, but from within the writer himself. "Inspiration" came to be explicated in terms of original genius, with the consequence that the inspired work was made peculiarly and distinctively the product-and the property-of the writer. ${ }^{19}$

It is the application of this eighteenth-century notion-with its romantic, anti-commercial overtones-to Shakespeare's sixteenth and seventeenth-century works that manages to cloud the waters so thoroughly.

Most of the heretical theorists and the bardolators are not literary scholars or historians. They are lawyers, doctors, journalists-people skilled in argument-who make the understandable mistake of assuming that the romantic conception of authorship really expresses a timeless truth about Art, rather than a 200 year-old stereotype. Applying their ahistorical stereotype to Shakespeare's life, they find-surprise, surprise-that it does not fit. For the bardolators the answer is simply that we sail off into the world of fantasy. For the heretics the answer is that a new author must therefore be found, one whose life and attitudes have a closer fit to the romantic conception of the author. Both groups, "knowing" that they are right, produce a set of arguments which confirm themselves even as one watches.

There is another, deeper implication to be drawn from this potted history of authorship. Many of our assumptions about the interpretation of texts depend on the romantic conception. The author's intent is the real meaning because the author's genius created this work out of nothing. As I pointed out earlier, the Founding Fathers are seen as both literal and figurative "authors" of the Country, the

19. Woodmansee, supra note 5, at 427 (footnote omitted). 
people who created a structure ex nihilo. The romantic conception tells us that the author's intent is qualitatively different from otherderivative, partial, political-interpretations of the work. The same claim is made for the intent of the Framers. The romantic vision ascribes to the author a temperament, insight, and genius that put her outside of society. The Founders are conceived as being outside of, as being the architects of, this society. Politics goes on inside the structure they have created, but the structure itself is seen as fixed by their will and our (tacit) acceptance of it. The list of similarities could be extended and extended. Yet under an older view, authors-whether constitutional or literary-are not seen as transcendental genii, but as the nodal points at which craft and divine inspiration converge. Such a view might have interesting consequences for constitutional theory. Perhaps the Constitution we have given our tacit consent to is not the one in the minds of the men at Philadelphia but the one in the minds of the theorists from whose ideas they borrowed, or the one that succeeding generations have believed they were living by, or the one we choose to make out of the conflicting traditions they left us. Perhaps it is some combination of all of these. In any event, once one challenges the romantic conception of authorship, all kinds of things start to happen.

So far, I have argued that it is the romantic conception of authorship that makes Shakespeare's identity appear to be a puzzle. Yet there are many arparent puzzles in the world. Why does this one attract such obvious passion from its devotees? Again, I think that the answer is linked to the romantic conception of the author, but this time it is linked more to the relationship we assume between the intention of the author and the meaning of his work. This is the point at which I see the closest parallel between the debate over Shakespeare's authorship and the debate over the interpretation of the Constitution according to the "Original Intent of the Framers."

Like the Constitution, Shakespeare's oeuvre presents us with an astounding range of possible meanings. Is Hamlet an Oedipal psychodrama, an existentialist tragedy, an attack on Machiavellian court intrigue, or a blood and thunder melodrama with a particularly inept hero? When the first amendment says no law shall abridge, does it mean no law? Is Shylock a convenient textual device to express anti-semitic feeling or a hero who cries out against the prejudice of his world? Does the fourteenth amendment require us to desegregate schools, or merely to give all children separate but equal educations? This kind of indeterminacy makes people extremely uncomfortable. Faced with such a range of possible interpretations, our first instinct is to turn to the intention of the author. We say 
that the text means what the author meant it to, and thus we limit the text's indeterminacy, its range of meanings.

There is a strange irony here. As I pointed out earlier, one of the reasons that it seems normal to concede to the author the power to rule the interpretation of the text is that the romantic vision portrays the author as a transcendent genius, full of limitless inventiveness. Yet here the author's main function seems to be as a device to limit and restrict the meaning of the text. Foucault describes this process in the article which I quoted at the beginning of this essay.

The author allows a limitation of the cancerous and dangerous proliferation of significations within a world where one is thrifty not only with one's resources and riches, but also with one's discourses and their significations. The author is the principle of thrift in the proliferation of meaning. As a result we must entirely reverse the traditional idea of the author. We are accustomed, as we have seen earlier, to saying that the author is the genial creator of a work in which he deposits, with infinite wealth and generosity, an inexhaustible world of significations. We are used to thinking that the author is so different from all other men, and so transcendent with regard to all languages that, as soon as he speaks, meaning begins to proliferate, to proliferate indefinitely. The truth is quite the contrary: The author is not an indefinite source of significations which fill a work; the author does not precede the works, he is a certain functional principle by which, in our culture, one limits, excludes, and chooses; in short, by which one impedes the free circulation, the free manipulation, the free composition, decomposition, and recomposition of fiction. In fact, if we are accustomed to presenting the author as a genius, as a perpetual surging of invention, it is because, in reality, we make him function in exactly the opposite fashion. One can say that the author is an ideological product, since we represent him as the opposite of his historically real function. ${ }^{20}$

This still leaves us with an important question. Shouldn't the interpretation of a play be governed by the author's intention? One set of objections concerns the other possibilities. Perhaps we should interpret texts as they would be understood by some real or imaginary community of readers. Or perhaps we should take the words at face value (whatever that means), only turning to some other interpretive criteria when this one runs out. Or perhaps we should interpret texts so as to give effect to some overriding goal-such as economic efficiency for law, or the development of the genre for literature-seeing each word as a mere placeholder for the end we

20. Foucault, supra note 1 , at 158-59. 
have in mind. Each of these ideas has had many a polysyllable devoted to its theoretical background (for example, are there essential meanings to words?) as well as to its practical problems (for example, who defines the relevant community of readers?). Each theory can subsume or be subsumed by any of the others. For example, you can't decide the goal of your interpretation without having some audience in mind, but in order to delimit the audience you need to postulate some goal.

Authorial intent has all of the same problems-as any literary biographer or lawyer researching congressional intent can testify. Again, the problems are both practical and theoretical. The practical problems concern the "when," "where," "how," and "which" questions about interpretation. Is Kafka's desire to have Max Brod burn his books part of his authorial intent? Does the corruptly bought vote of a legislator form part of the congressional intent? The theoretical problems concern the "why" questions. For example, why should we say authorial intent governs when the concept of intent cannot be easily understood without reference to some imagined audience-even if it is an internal one? Why should we think the author's intent governs when an older conception presents the author as the nodal point at which the received learning and the muses' dictates make themselves concrete? Why not cast our interpretive nets back into the culture from which the work sprang, or forward into the audience that now receives it? To explain the full background to all of these interpretive theories would take hundreds of pages. I have neither the time nor the talent necessary to weave the whole tangled web, but I think I can make at least a couple of points without doing so.

There are so many problems with the theory of authorial intent, and we turn so frequently to other methods of interpretation, that the dominance of the theory cannot be explained by reference to its accuracy. ${ }^{21}$ To understand its appeal we must turn to the image that it conjures up, the image I described in the section on the romantic conception of authorship. The image is of a self-willed, autonomous, creative individual who maintains control over the fruits of her labor. This is not merely a literary convention, it is a utopian political ideal familiar from the works of writers from Locke to Marx. Of course, when one appeals to the intent of the author, one conjures up not merely the romantic conception of the great writer, but also a much more common sense idea about the person who is

21. But see Nehamas, What an Author Is, 83 Journal. Of Philosophy 685 (1986); Nehamas, The Postulated Author: Critical Monism as a Regulative Ideal, 8 CrItICAL Inquiry 133 (1981). 
most likely to understand a text. Yet both the common sense and the romantic ideas resonate strongly with our utopian visions. In the Marxist vision of society as well as in the Byronic vision of authorship the romantic idea of making history with will and consciousness is balanced by the more prosaic goal of achieving control over one's own labor. At the same time there is also a powerful appeal to our subliminal desires for author-itarian control. We will not have to make any hard decisions because the author has made all of the necessary choices already. Peter Gabel calls this syndrome in constitutional jurisprudence "Founding Father knows best."22 Thus, the theory of authorial intent gives the appearence of being both romantic and pragmatic, common sense and philosophically sophisticated, emancipatory and authoritarian, property and antiestablishment. Small wonder that it seems to be a qualitatively superior mode of interpretation. Like Walt Whitman, it contains multitudes.

Lawyers are familiar with the range of moral, practical, and conceptual problems presented by the theory of authorial intent. $\mathrm{Mr}$. Meese's Justice Department argues that the interpretation of the Constitution should be governed by the intentions of the small group of white males who created the text. It is pointed out that this type of interpretation is frequently historically uncertain, practically indeterminate, politically repugnant, conceptually incoherent, and contraindicated by the evidence that the Framers' intent was that the Framers' intent should not bind future generations. ${ }^{23}$ If we brush aside these trifling objections, how does all of this relate to the Shakespeare debate?

If one wishes to limit the indeterminacy of Shakespeare's texts by interpreting them according to the author's intentions, one runs into two major difficulties; one theoretical, one practical. The theoretical difficulty is the question of whether an author's intention should govern the interpretation of the author's work. From what I have just been arguing it seems to me that the answer is that authorial intent is at best one of a grab-bag of interpretive methods, none of which can claim unique correctness. But let us assume for a moment that we accept the correctness of the theory. The practical difficulty is more down to earth. We know so little about the intimate details of William Shakespeare's life. We wish to know more about what he thought, what he dreamed of, his relations with his

22. Gabel, Founding Falher Knowus Best 2 Tiknux 41 (1986).

23. See generally Powell, The Original l'ndersianding of Original Intent, $98 \mathrm{HARv}$. L. REv. 885 (1985); Tushnet, Following the Rules Laid Doum: A Gritique of Interpretation and Aeutral Principles. 86 HaRv. L. REv. 781 (1983). 
loved ones, his interests, background, schooling, and so on. Without this kind of detailed picture (and perhaps even with it) how could we know the real meaning of the plays and poems? At the moment a question mark hangs behind the works. We wish that we could subsitute for this question mark a person fully detailed in every part. From the wish to the deed is but a short step.

The road now leads in three different directions. Frustrated by this dearth of information, Shakespearean popularizers construct the persona from the texts and then use this constructed persona to interpret the plays they have just been mining for clues. Lawyers are very familiar with this "procedure." Admittedly, it may seem a trifle circular (as indeed it is), but what it lacks in methodological coherence it makes up in illusory but comforting certainty. In the next section I will give an example of the things that can be done with this kind of interpretive method.

On the second fork of the road are the heretics. Similarly frustrated by the lack of information, their solution is to substitute for William Shakespeare another person about whom we know more. In fact, the one quality shared by all fifty-six alternate candidates for Shakespeare's title is that we know more about them than we do about the unromantic actor and theatrical entrepreneur from Stratford on Avon. It seems that any kind of biographical determinacy, no matter how wildly unlikely, is preferable to an author about whom we know next to nothing. With the new author in place, the texts can be reinterpreted. In the Oxfordian version it turns out that the farcical bedroom substitutions of one woman for another must be events from de Vere's own life, the fuel for Hamlet is de Vere's own resentment against Burleigh, and so on. ${ }^{24}$

The third fork of the road is probably the least travelled, although perhaps the most interesting. Might we not like our authors to be faceless and featureless? Might we not prefer to have Shakespeare as a mystery, his character unrecorded, or his identity actually unknown? My favorite passage on the subject comes from Sartre.

Nevertheless, I had to be told about authors. My grandfather told me, tactfully, calmly. He taught me to recite the list to myself, from Hesiod to Hugo, without a mistake. They were the Saints and Prophets. Charles Schweitzer said he worshipped them. Yet they bothered him. Their obstrusive presence prevented him from attributing the works of Man directly to the Holy Ghost. He therefore felt a secret preference for the anonymous, for the

24. For the general form of the argument see J. Looney, Shakespeare Identified in Edward De Vere, Seventeenth Earl of Oxford, And the Poems of Edward De Vere, 135 245 (1949); C. OGBURN, supra note 11, at 359-60, 365-72, 488-91, 575-76, 613-14. 
builders who had had the modesty to keep in the background of their cathedrals, for the countless authors of popular songs. He did not mind Shakespeare, whose identity was not established. Nor Homer, for the same reason. Nor a few others, about whom there was no certainty they had ever existed. As for those who had not wished or had been unable to efface the traces of their life, he found excuses, provided they were dead. ${ }^{25}$

Both Henry James and Borges have written stories in which a different version of this idea features. In James' The Birthplace ${ }^{26}$ a man becomes the caretaker of Shakespeare's birthplace. At first, he tries to tell the visitors that we know nothing about Shakespeare. " '. . . It's all I want-to let the author alone. Practically'-he felt himself getting the last of his chance-'there is no author; that is for us to deal with. There are all the immortal people-in the work; but there's nobody else." "27 $\mathrm{He}$ meets with a uniform hostility to this idea. Finally, he starts to make up anecdotes giving complete, and completely spurious, details of Shakespeare's private life. His audiences are enthralled, his salary is raised-all as payment for refusing to "let the author alone."

This theme is repeated in Borges's story, Everything and Nothing. This Shakespeare has acted many parts, but has never had a self-a core. He speaks of this to God, but Borges' God is a modernist. "Neither am I anyone; I have dreamt the world as you dreamt your work, my Shakespeare, and among the forms in my dream are you, who like myself are many and no-one." 28

\section{III}

Leaving the beguiling notion of an eternally indefinite Shakespeare, let us return to our main theme. I have argued that the Oxfordians start with the romantic conception of the author, reject William Shakespeare because he does not fit it, substitute for him a person who does fit the image and whose life is nearly contemporaneous, and thus dispell the threatening question mark that hangs behind the works. Edward de Vere's persona is not only knowable but known, and the plays become a vaguely disguised version of the

25. J. SARTRE, The Words 61-62 (1964). I offer this as my modest contribution to the heretics, for their collection of quotations showing that famous people have doubted Shakespeare's authorship.

26. James, The Birthplace, 17 The New York Edition Of Henry James 129 (1909).

27. Id. at 180 .

28. Everythmg and Nothing, in J.L. Borges, Labyrinths 249 (1964). The best source for different views of Shakespeare is S. Schoenbaum, Shakespeare's Lives (1970), which is not a biography of Shakespeare, but a biography of his biographers. After reading Professor Schoenbaum's work, it is clear that everyone 'finds' the author for whom they were searching. 
author's own life. This reading manages simultaneously to exalt individualism, the nobility, ahistorical interpretation, and the use of the Author as "the principle of thrift in the production of meaning." Mr. Meese would be proud. But it would hardly be fair to concentrate only on the heretical and bardolatrous scholarship. I will turn now to those whose "search for the author" consists of their attempt to enlist Shakespeare's transcendental genius in support of their own vision of life, the state, or sexuality. Again there is a close relationship between the attempt to capture Shakespeare and the romantic conception of authorship. In fact, he is worth "capturing" precisely because of the qualities which the romantic conception of the author ascribes to him. After all, if Shakespeare believed it, it must be true.

I will use as an example that eminent popularizer of the Elizabethan period, Mr. A.L. Rowse and his revealingly titled biography, Shakespeare the Man.29 As we will see, there are some indications that the last word of the title should be in capital letters.

If we accept the romantic conception of the author, then the opinions and predilections of the author assume an unusual importance. After all, if the author is a transcendental genius surely we should give extra weight to his ideas, his political beliefs, even his sexual orientation. Now, some-perhaps most-readers of the Sonnets have found in them fairly strong homoerotic overtones. If many of the addresses to the fair youth seem to smack of the love that dare not speak its name, should we therefore conclude that Shakespeare was ... ? Mr. Rowse is quick to disabuse us of the idea that we should give the sanction of the Great Author to gay love. In fact, almost every time that Shakespeare's bawdiness is mentioned $\mathrm{Mr}$. Rowse reassures(?) us that we should not draw any conclusions about the breadth of the bard's sexual enthusiasm. "Shakespeare is the bawdiest of the Elizabethan dramatists, with the natural bawdy of the highly sexed normal heterosexual, ..."30 Even when we might be thinking of something other than sexual preference-such as the poetry, for example-Mr. Rowse manages to retrieve our straying attention with his subtle commentary.

"Past cure I am now, now reason is past care,

And frantic-mad with evermore unrest" 31

This is what sex can do for highly sexed heterosexuals. In case we might have missed the fact that SHAKESPEARE WAS A HETERO-

29. A.L. Rowse, Shakespeare The Man (1973).

30. Id. at 46 (emphasis added).

31. Id. at 97. 
SEXUAL Mr. Rowse quotes some of the bawdier passages from the sonnets and reminds(?) us that "[i]t is a well known psychological phenomenon that homosexuals do not go in for this kind of bawdiness." 32

Well, one lives and learns. Finally, lest we think it was only the playwrights who were butch, Mr. Rowse manages to get in some words about the audience. The following example comes in the middle of a reproof he aims at the Victorians for their censure of the brothel scenes in Pericles. "[T]he bawdy is natural and would appeal to an Elizabethan audience, neither incestuous nor homosexual." 33 With Mr. Rowse it is never terribly easy to tell, but I assume that the last two adjectives refer to the audience rather than the bawdy. Am I wrong then, to detect an implied judgement about the characteristics of today's theatre audiences? Perhaps I digress.

In Mr. Rowse's hands Shakespeare not only lends his author-ity to heterosexuality, he also provides a justification for social hierarchy. Mr. Rowse relies most heavily on Coriolanus to make his point.

In his play Shakespeare concentrates on the issues of dearth of corn, class-conflict, the pros and cons of peace or war, all beating against the rock-like figure of a war-hero who cannot adapt himself to peace, let alone democracy and democratic humbug. Some humbug is a necessary element in a society, a kind of cement helping to keep it together; but if all is humbug-one thinks of the 1930 s, before the war, and again ever since-society falls apart. ${ }^{34}$

Having quoted other passages from Coriolanus and Antony and Cleopatra to show that Shakespeare thought the mob contemptible, the people incapable of operating without direction, Mr. Rowse sums up in the following way.

[T] intellectuals in control of the mass media of democratic society, are bent on courses utterly contrary to honesty and common sense, contrary to the facts of human nature and society, victims of their own illusions and the propagators of lies. It is not true, and it never has been true, that men are essentially reasonable, non-violent, infinitely educable, and that they can be left to govern themselves by their own sweet will. The consequences of the inculcation of these delusions are to be seen on every hand in democratic society today. As if William Shakespeare, than whom no man has ever understood more thoroughly, was wrong and superficial liberal intellectuals right! ${ }^{35}$ 
I am struck particularly by the explicit use of Shakespeare's genius to buttress the argument against social equality. This is, literally, an argument from author-ity. Shakespeare the great author had this opinion and this "fact," is a sufficient warrant of the opinion's truth. Substitute "the Framers" for Shakespeare and "binding quality" for truth and you have the theory of Original Intent. But the similarities go beyond mere methodological agreement; there seems to be some agreement about politics too. In conclusion, Mr. Rowse has this to say about "[t]he cult of the common man." "[It] is the greatest enemy of incentive, quality, achievement; in itself it is a lie-as the people themselves well know-and its propagation eats away the heart-strings that hold society together."36 By themselves, Mr. Rowse's political opinions might not carry much weight. (Might we say the same about Mr. Meese?) Popularizing historians and literary biographers are not normally thought of as the most perspicacious of political observers. (Might we say the same about Attorneys General?) But because of his status as a literary scholar we will probably grant Mr. Rowse's interpretation of Shakespeare a certain authority. And if Shakespeare (rather than Mr. Rowse) is against social egalitarianism, (and is very, very heterosexual). . .well, this is a dark lady of a different color entirely. Interestingly, Mr. Meese's Framers also seem to be against social egalitarianism. They even seem to be very, very heterosexual. No doubt this is just a coincidence.

\section{Conclusion}

I started this essay with a quotation from Michel Foucault-a man whose historical generalizations would be completely insufferable if they weren't so often correct. I finish the essay convinced that a lot more historical and philosophical work needs to be done on this notion of an author. The notion has its repressive side, its willingness to cede control to the (supposed) will of some unseen presence-"Founding Father knows best." This may be the most striking parallel between the Shakespeare debate and constitutional jurisprudence. But the notion of the author also has its emancipatory side. The very attractiveness of the idea of "the author" springs from the vision it conjures up-making history with will and consciousness, engaging in fulfilling, creative labor, not reducing everything to the universal logic of the money relation, keeping control over the objects one produces. This sounds like Marx

36. Id. at 225 . 
writing about alienated Labor as well as Kant writing about the universality of the Subject.

Finally, there is the eerie resemblance between the romantic conception of the author and the romantic conception of the family. Both art and the family come to be seen as a source of immortality, a non-instrumental arena for passionate self-expression, a haven from the pressures of commerce and so on. My suggestion is that-if we trace out the historical development of these ideas in their economic and cultural contexts-we will find a whole series of parallels, even though the reality that is supposed to be "represented" by these conceptions is actually very different (and much more complicated). Where all of this might lead I do not know, but I would like to suggest that it might lead us to a "political economy of our metaphysics;" a way of understanding the historical genesis of the fundamental notions (public/private; art/commerce; intentional/accidental) with which we structure our world. The history of authorship bids fair to be the first part in this study. But that is for another article. Where does all of this leave poor Will?

Take your pick. The authoritarian, bawdy, and fiercely heterosexual playwright beloved of Professor Rowse, the transcendental genius who rises amidst choirs of angels, the professional Elizabethan playwright obsessed by language, hammering away at his craft and incidentally creating something that has lasted long beyond the world in which the works originated, the question mark hanging just out of sight behind the plays, the riddle wrapped in a mystery wrapped inside an enigma. Is he the Earl of Oxford? Francis Bacon? Queen Elizabeth herself? The struggle continues, the arguments looping back through the texts to confirm themselves in the minds of their progenitors, providing us with a veritable treasury of circular reasoning and self-validating theories. Arguments over the intent of the Framers pale in comparison. The factions struggle to restore determinacy or indeterminacy to the texts, to show that the plays give the sanction of genius to social hierarchy or that the sonnets are a hymn to a lust unbesmirched by homoeroticism. Do the arguments that follow address the question, "Who was Shakespeare?" Yes they do although, as I have tried to show, they are far from alone in their attempt to capture Shakespeare. But Shakespeare remains undepicted, uncaptured-and so ... gentle "Reader looke, not on his Picture, but his Booke."37

37. Ben Jonson. To The Reade, in The Riverside Shakespeare 58 (G.B. Evans ed. 1974). 
